\title{
QUALITY ASSURANCE AND ACCREDITATION OF ENGINEERING PROGRAMMES AT THE FACULTY OF ENGINEERING AT THE UNIVERSITY OF THE WEST INDIES, ST. AUGUSTINE CAMPUS, TRINIDAD
}

\author{
Edwin I. Ekwue \\ Faculty of Engineering, The University of the West Indies, Trinidad \\ Email: Edwin.Ekwue@sta.uwi.edu
}

\begin{abstract}
The quality of engineering education is challenging and is of paramount importance in today's globalised world. The Faculty of Engineering at the University of the West Indies (UWI), St. Augustine Campus, inherited a western education system and the accreditation systems in the five departments within the Faculty are based on the British accreditation system. The aim of this paper is to describe how this accreditation system is utilised in the Faculty of Engineering to ensure that the quality of the delivery of its programmes is at a high standard. The paper was derived from a survey carried out by the author. It describes the quality systems available in the Faculty and fully describes the steps involved in the accreditation process. The paper reveals the recent attempt at introducing the Caribbean Accreditation Council for Engineering and Technology (CACET) but concludes that until it is fully established and internationally recognised through its membership in the Washington Accord or any other comparably recognized international body, there will still be room for the international accreditation by the British institutions or other comparative international institutions at the Faculty of Engineering at UWI.
\end{abstract}

Keywords: Accreditation, quality, engineering, Faculty, British

https://doi.org/10.47412/ZFPX9078

\section{Introduction}

An aspect of globalization is the free movement of professionals and services across national boundaries. This mobility has created unique opportunities for the flow of technology, knowledge, people, skills, money, transhipment of industries, goods and services, values and ideas across the borders [1]. Engineering education is greatly involved in this globalization process since engineering graduates from a country can undertake employment in another country through permanent or temporal relocation. For instance, since the Caribbean region is geographically located between the Americas and Europe, university graduates from the region seek to better themselves financially by migrating to North America, including United States of America and Canada or the United Kingdom (UK) for employment, or to further their studies. The international mobility of engineering graduates has compelled educational institutions to enhance the quality and standard of their deliveries by introducing and pursuing various assurance and professional 
accreditation processes [1]. Accreditation of engineering educational programmes as entry route to the engineering profession has proved to be a powerful tool to improve both academic quality and relevance for the job market [2].

\section{Definition and Systems of Accreditation}

Educational accreditation is the evaluation of an educational institution or programme by an independent body of professionals. It signifies both recognition given to a programme as meeting applicable criteria as a result of an evaluation process and the process itself [3]. Accreditation helps to ensure that regardless of the department's mission, the academic offerings meet the standards set by the accrediting body. Developing countries do not have the industrial maturity and reputation of industrialized countries. They therefore adopt or develop systems of accreditation that are at once internationally recognised and at the same time relevant to the local conditions [4]. The systems of accreditation, where they exist in most former British colonies (including the English speaking Caribbean countries) are well structured, national in scope and independent of the engineering schools and governments, in line with the requirements of the Washington Accord [4]. The Washington Accord of 1989 [5] represents a major effort to internationalise engineering education [6] and represents an agreement for mutual recognition of accredited professional engineering academic qualifications among the English-speaking countries of the world. These foundation member countries and their representative professional bodies [1] are: Australia (IEAust, 1989), Canada (Engineers Canada, 1989), Ireland (Engineers Ireland, 1989), New Zealand (Institution of Professional Engineers NZ, 1989), United Kingdom (Engineering Council UK, 1989), and the United States of America (Accreditation Board for Engineering and Technology, 1989). Today, there are 15 signatories to the Washington Accord that together deliver over 7,000 programmes [5]. Six countries maintain provisional status in the accord. The Washington Accord itself is a constituent of the International Engineering Alliance (IEA) which comprises educational accords for professional engineers, engineering technologists and engineering technicians plus two professional engineering and one engineering technologist competency agreements [5]. The IEA is concerned with engineering education and competence across the whole spectrum of engineering. The accreditation systems in North America and United Kingdom are used by universities and technical schools in several other countries and are the ones that are usually used in the Caribbean region [4]. The two systems of accreditation are similar, except that the American System is more output based and the British system is more prescriptive [4]. In the Faculty of Engineering at UWI, St. Augustine Campus, the British System is utilised, mainly because of the historical links with the UK.

\section{Quality Assurance and Accreditation System Adopted at the Faculty of Engineering at St. Augustine Campus}

\subsection{Brief Description of The UWI and Faculty of Engineering, St. Augustine Campus}

The University of the West Indies (UWI) serves 17 English-speaking states in the Caribbean that were former British colonies [7]. It has a current enrolment of close to 50,000 students and graduates about 10,000 students per annum [7]. There are five major campuses. The University started with a Campus in Mona, Jamaica in 1948 with 33 medical students, first as a University College of the West Indies, which was a College of University of London, becoming an 
independent University in 1962. The St. Augustine Campus was established in 1960 in Trinidad using the then existing facilities of the Imperial College of Tropical Agriculture. Cave Hill Campus followed in 1963 in Barbados while the Open Campus was inaugurated in 2008. The Five Islands Campus in Antigua and Barbuda was established in 2019. In addition to the five main campuses, there are University Centres, in the other territories that comprise the University. As part of its current globalisation agenda, UWI has established partnership centres with Universities in North America, Latin America, Asia and Africa [7].

In 1961, the Faculty of Engineering was started in St. Augustine Campus in Trinidad with 28 students which has now grown to more than 1800 students pursuing Bachelor's, Master's and Doctoral degrees. During 1961/62 Academic year (the first year of teaching), the Faculty initially offered undergraduate and graduate research degrees in the main branches of Engineering Chemical, Civil, Electrical and Mechanical. The Faculty steadily grew over the years with a major expansion of both physical infrastructure and academic programmes leading in the 1980's to the establishment of additional disciplines at the BSc level and several specialist MSc degrees [8]. The Faculty now comprises of five (5) academic departments, having added Geomatics Engineering and Land Management. In 2018, a second Faculty of Engineering was established on the Mona Campus of the University.

\subsection{Quality Assurance and Accreditation System at Faculty of Engineering, St. Augustine Campus}

From the start, the Faculty of Engineering at St. Augustine adopted the British approach of quality assurance including the comprehensive external assessment, whereby all examination materials are scrutinised by external examiners from outside the University and region. Other quality assurance measures adopted over time included the instituting of the student/staff liaison, industrial liaison and curriculum committees as well as the personal tutor-tutee system. There was also the setting up of quality assurance offices, quality units and quality manuals, as well as ensuring that regular departmental and Faculty board meetings are held, aimed at improving the quality of delivery in the Faculty of Engineering. In the 1980's and 1990's, with the increased need to ensure the provision of programmes of very high quality, the departments in the Faculty invited the British Institutions to accredit their programmes. The Mona Campus adopted the American system for the accreditation of its engineering programmes and this is not seen as a major problem, since the two accreditation systems are signatories to the Washington Accord. The list of the programmes in the Faculty of Engineering at St. Augustine so far accredited is shown in Table 1. The information was obtained directly from the various departments in the Faculty.

In the UK, the Engineering Council has the overall responsibility for establishing and maintaining the standards both of the accreditation of engineering degree programmes, and of the registration of qualified professional engineers [2]. The UK accreditation system was well described by [2]. The standards for registration are designed in terms of competences published in the UK Standards for Professional Engineering Competence (UK-SPEC) [9]. The usual route for achieving the required competences is obtaining an accredited engineering degree, followed a period of initial professional development and then a demonstration of professional responsibility. The Engineering Council itself does not conduct accreditations, but licences the discipline-specific Professional Engineering Institutions (PEIs) [2]. In Table 1, it was indicated that the PEIs that accredit the programmes in the Chemical Engineering department are the Institution of Chemical 
Engineers, UK and other Institutions. A Joint Board of Moderators (JBM) made up of the Institutions of Civil, Structural and Highway Engineers, is responsible for accrediting the Civil Engineering programmes. Institute of Engineering and Technology (IET) accredits the Electrical and Computer Engineering programmes while the Chartered Institute of Civil Engineering Surveyors accredits the Geomatics Engineering programme. The programmes in the department of Mechanical and Manufacturing Engineering are accredited by the Institute of the Mechanical Engineers, of the UK (IMechE).

The requirements in the UK-SPEC for the accreditation of engineering programmes are expressed in the form of learning outcomes that are applicable to all the engineering disciplines. They are interpreted by each of the PEIs to reflect their particular discipline [2]. The UK-SPEC output standards are of two types:

Table 1. Status of Accreditation of Undergraduate and Postgraduate Programmes at the Faculty of Engineering in 2019

\begin{tabular}{|c|c|c|c|}
\hline Departments & Programme & $\begin{array}{c}\text { Period of } \\
\text { Accreditation }\end{array}$ & Accrediting body \\
\hline \multirow{9}{*}{ Chemical Engineering } & BSc Petroleum Geoscience & 2016-2022 & $\begin{array}{l}\text { The Geological } \\
\text { Society of London }\end{array}$ \\
\hline & BSc Petroleum Geoscience & $2017-2021$ & Energy Institute, UK \\
\hline & $\begin{array}{c}\text { BSc Chemical and Process } \\
\text { Engineering }\end{array}$ & \multirow{4}{*}{ 2016-2020 } & \multirow{4}{*}{$\begin{array}{c}\text { Institution of Chemical } \\
\text { Engineers, IChemE, } \\
\text { UK }\end{array}$} \\
\hline & $\begin{array}{l}\text { MSc Chemical and Process } \\
\text { Engineering }\end{array}$ & & \\
\hline & $\begin{array}{c}\text { MSc Chemical and Process } \\
\text { Engineering with Management }\end{array}$ & & \\
\hline & $\begin{array}{c}\text { MSc Chemical and Process } \\
\text { Engineering with Environmental } \\
\text { Engineering }\end{array}$ & & \\
\hline & MSc Petroleum Engineering & 2015-2019 & $\begin{array}{l}\text { The Institute of } \\
\text { Materials, Minerals } \\
\text { and Mining, UK }\end{array}$ \\
\hline & MSc Petroleum Engineering & & \\
\hline & MSc Reservoir Engineering & 2017-2021 & Energy Institute \\
\hline \multirow{5}{*}{$\begin{array}{l}\text { Civil and } \\
\text { Environmental } \\
\text { Engineering }\end{array}$} & MSc Civil Engineering & \multirow{5}{*}{$2015-2020$} & \multirow{5}{*}{$\begin{array}{l}\text { The Joint Board of } \\
\text { Moderators (JBM), } \\
\text { UK (Institutions of } \\
\text { Civil, Structural \& } \\
\text { Highway Engineers) }\end{array}$} \\
\hline & $\begin{array}{l}\text { MSc Civil with Environmental } \\
\text { Engineering }\end{array}$ & & \\
\hline & MSc Construction Management & & \\
\hline & BSc Civil Engineering & & \\
\hline & $\begin{array}{l}\text { BSc Civil with Environmental } \\
\text { Engineering }\end{array}$ & & \\
\hline \multirow{2}{*}{$\begin{array}{c}\text { Electrical and } \\
\text { Computer Engineering }\end{array}$} & $\begin{array}{l}\text { BSc Electrical and Computer } \\
\text { Engineering }\end{array}$ & \multirow[t]{2}{*}{ 2020-2022 } & \multirow{2}{*}{$\begin{array}{l}\text { The Institute of } \\
\text { Engineering and } \\
\text { Technology (IET) }\end{array}$} \\
\hline & $\begin{array}{l}\text { MASc Electrical and Computer } \\
\text { Engineering }\end{array}$ & & \\
\hline $\begin{array}{c}\text { Geomatics Engineering } \\
\text { \& Land Management }\end{array}$ & BSc Geomatics & $2017-2020$ & $\begin{array}{c}\text { Chartered Institute of } \\
\text { Civil Engineering } \\
\text { Surveyors) }\end{array}$ \\
\hline
\end{tabular}




\begin{tabular}{|c|c|c|c|}
\hline \multirow{8}{*}{$\begin{array}{c}\text { Mechanical \& } \\
\text { Manufacturing } \\
\text { Engineering }\end{array}$} & BSc Mechanical Engineering & \multirow{8}{*}{ 2016-2020 } & \multirow{8}{*}{$\begin{array}{l}\text { Institution of } \\
\text { Mechanical Engineers, } \\
\text { IMechE, UK }\end{array}$} \\
\hline & BSc Industrial Engineering & & \\
\hline & $\begin{array}{c}\text { BSc Mechanical Engineering with } \\
\text { a Minor in Biosystems }\end{array}$ & & \\
\hline & $\begin{array}{l}\text { MSc Production Engineering \& } \\
\text { Management }\end{array}$ & & \\
\hline & MSc Production Management & & \\
\hline & MSc Engineering Management & & \\
\hline & $\begin{array}{l}\text { MSc Engineering Asset } \\
\text { Management }\end{array}$ & & \\
\hline & $\begin{array}{l}\text { MSc Manufacturing and } \\
\text { Engineering Management }\end{array}$ & & \\
\hline
\end{tabular}

General Learning Outcomes, which are applicable to all the programmes, and the Specific Learning Outcomes, which apply to the particular discipline. The broad areas of the output standards under the General Learning Outcomes include knowledge and understanding, intellectual abilities, practical skills and

general transferable skills. The Specific Learning Outcomes include underpinning science and mathematics, engineering analysis, design, economic, social and environmental context and engineering practice [2].

Figure 1 shows the typical steps normally adopted by the PEIs during the accreditation process. The accreditation process is initiated by the particular department in the Faculty of Engineering. The PEI receives the request and agrees on a target date for the accreditation or re-accreditation visit with the department as well as the deadline date for the receipt of the required detailed documentation that explains how the degree programmes meet the learning outcomes of UKSPEC. Table 2 shows a typical detailed documentation required by the PEIs. The documentation includes information on the details of teaching and learning assessment strategies, the human and material resources available, quality assurance arrangements, the admission of students for the programmes and how the cohort entry standard will be supported (Table 2). The PEI appoints an accreditation team to investigate the claims made in the documentation and to make arrangements for a visit to the department. The panel normally includes academic and industrial members trained in the principles of accreditation and conversant with the requirements of accreditation. The visits are typically two to four days' duration and the panel meets staff, students, visits library, laboratory and studio resources, and scrutinises student output including examination papers, projects and other assessed student work, and reports to ascertain if the required learning outcomes are being met. The team normally pays visits to the Faculty Dean, the Campus Principal and other officials from the St. Augustine Campus including the Registry. Essentially, the aim of the panel is to seek evidence that the claim that the content and standard of the programmes in a particular department meet the specific learning outcomes, and that the resources required are adequate to achieve the stated outcomes [2]. Each PEI has a relevant committee or board that will decide, based on the report from the accreditation panel, whether or not to accredit or re-accredit the programmes. Accreditation is normally up to five years, although it could be for three years, if some aspects of the programmes are judged to require development or enhancement. Shorter periods of accreditation are at times given in case of new programmes [2] or in case the accreditation panel dictates serious faults with the programmes. 


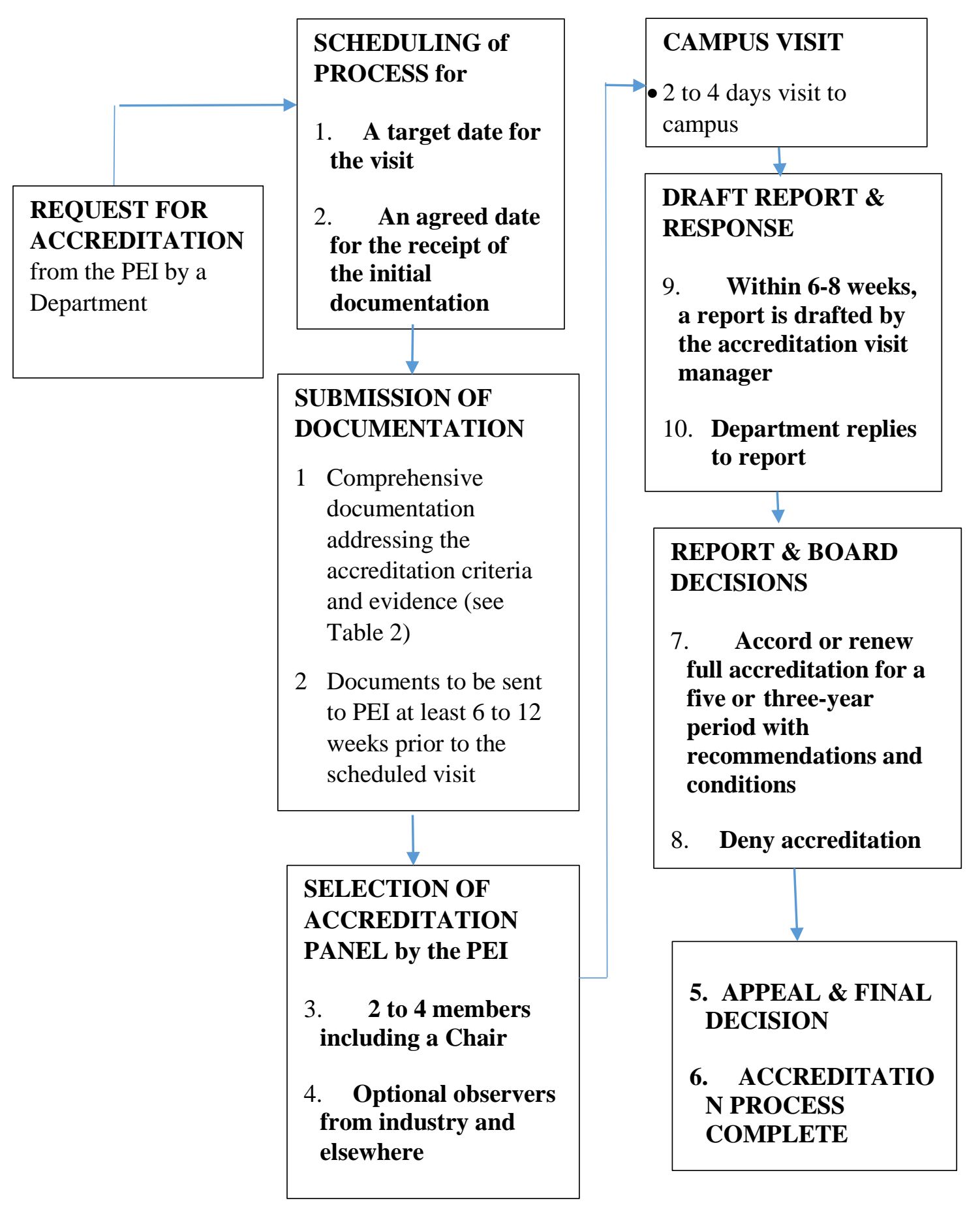

Figure 1. Typical steps involved in the British accreditation process for engineering programmes 
Table 2. Typical information required by accreditation bodies under the British Council

\section{SECTION A: GENERIC INFORMATION}

A1: General Information- General details including address of institution, programme details, programme specifications, programme learning outcomes A2: Quality Assurance: Institutional audit review, internal programme review reports, external examiner reports, departmental quality assurance management structure, departmental quality assurance management procedures

A3: Staff: Teaching staff, staff development and training, research engineer experience

A4: Resources: Facilities including laboratory equipment, finances, renewal plan; student experience including pastoral, academic and welfare support for students

A5: Past Changes and Future Plans and Intentions: Changes since last accreditation, planned changes

\section{SECTION B: COURSE INFORMATION}

B1: Programmes: Programme structure, Syllabus/module descriptors, examination papers

B2: Projects: Project list, Project failures, Project guidance

B3: Industrial Input and Influence: Industrial and research input, Industrial visits, Industrial placements, collaboration with industry

B4: Partnership Arrangements and Overseas Study: Period of study overseas, partnership arrangements, franchise arrangements

B5: Admissions, Progression, Award and Destination: Entry requirements, cohort Support, graduation, methods of assessment, progression, classification of degree B6: Professional Membership: Student Members, Professional Institutions

B7: Special/Commendable Features: Relevant special features

\section{SECTION C: OUTPUT STANDARDS MATRIX}

C1: Programme Content: Output Standards Matrix.

In 2001, the UWI went further and established a formal Quality Assurance Unit (QAU) within the Board for Undergraduate Studies (BUS) of the University [10]. The unit supports the quality mandate on behalf of BUS and the Board for Graduate Studies and Research (BGSR) of UWI. It assists departments with quality management systems by conducting quality assurance reviews, conducting internal audits and supporting the professional accreditation. The QAU, through panels conducts audits to evaluate the arrangements in all departments of the UWI to ensure that the teaching and learning environment is of appropriate standard, and is properly resourced, supported and monitored. The Information of the QAU audits are normally required during the accreditation process by the PEIs (see Table 2) so that the accreditation panels evaluating an engineering programme can then rely on the integrity of the assessment of the institutional 
processes, and can therefore concentrate directly on how these processes are practised in the programmes under investigation [2].

All the BSc. (Hons) degree programmes in Table 1 are accredited en-route to the chartered engineer status while the MSc. degrees are accredited to the chartered engineer status. An accredited engineering degree does not enable a graduate to register immediately as a professional engineer [2]. An accredited degree only provides the educational base which provides the levels of understanding, knowledge and skills required to support the development of the professional competences that are required to register as a professional engineer. To achieve chartered Status, a BSc. (Hons) degree and an appropriate Master's degree or further learning to Master's level are required [2]. After graduation, potential professional engineers need to undergo professional development typically three or four years before applying for registration with a relevant PEI.

The application should include information about their education, professional development and responsibility. Registration can also be done with appropriate Board of Engineering in the Caribbean region or elsewhere responsible for the registration of engineers. Although in the UK and most Caribbean countries, there is no formal obligation to register in order to practise the engineering profession, the regulations for the registration emphasise the importance of the accreditation of engineering degree programmes.

Imbert and Lewis [4] in 2004, proposed the establishment of a Caribbean engineering accreditation body that would eventually be given the responsibility for accrediting all engineering degree programmes in the Caribbean region. In 2009, the Caribbean Accreditation Council for Engineering and Technology, CACET [11] was officially established to accredit engineering programmes offered by the institutions in the Caribbean. Until CACET is fully established and internationally recognised through the membership in the Washington Accord or any other comparably recognized international body, there may still be room for the international accreditation by the British Institutions at the Faculty of Engineering at UWI.

\section{Concluding Remarks}

In order to ensure the best quality assurance and standard, the aim of all the departments in the Faculty of Engineering at The University of the West Indies in St. Augustine is to ensure that all their programmes obtain full accreditation by recognised institutions, in this case, the British Institutions. International accreditation provides the programmes with a stamp of approval and enhances the international status of the Departments, Faculty and the University, as a whole. It also provides graduates' confidence in their qualifications to be recognised globally. Since considerable number of graduates migrate for work and further studies, the professional accreditation provides the much-needed opportunity for UWI engineering graduates to seek professional employment worldwide, with minimum or no hassle. The British system of accreditation is thorough, is of a high standard, and is internationally recognised. Until the CACET, the newly formed regional engineering accreditation body is fully developed and functional, the use of the British institutions or other comparative international institutions to accredit programmes at the Faculty of Engineering at UWI, St. Augustine Campus is strongly advised. 


\section{References}

[1] H. Chowdhury, F. Alam, S.K. Biswas, M.T. Islam, A.K.M. Sadrul Islam. Quality assurance and accreditation of engineering education in Bangladesh. Procedia Engineering 56, (2013) 864 -869 .

[2] G. Augusti, I. Freeston, G. Heltmann, R. Martin. 2007. Accreditation of engineering programmes as a tool to assure academic quality and relevance for the job market. Implementing and Using Quality Assurance: Strategy and Practice, 2nd European Quality Assurance Forum, 116. Available at: https://www.enaee.eu/wp-content/uploads/2018/11/Rome-07-Augusti_elEQAF-paper1.pdf

[3] European Network for Engineering Education, ENAEE. 2015. Best Practice in Accreditation of Engineering Programmes: An Exemplar, 1-11. Available at: https://www.enaee.eu/wpcontent/uploads/2018/11/best_practice_2017_online.pdf

[4] C.A.C. Imbert, T.M. Lewis. Accreditation and mutual recognition of engineering qualifications in CARICOM. West Indian Journal of Engineering 26 (2), (2004) 55 - 64.

[5] Washington Accord (2014). Celebrating International Engineering Education Standards and Recognition. Available at:

https:/www.ieagreements.org/assets/Uploads/Documents/History/25YearsWashingtonAccordA5booklet-FINAL.pdf

[6] R.B. Vea. The importance of accreditation of engineering programmes to the global practice of the profession. Transactions of the National Academy of Sciences and Technology Philippines 29, (2007) $348-355$.

[7] The University of the West Indies Website (2020). Welcome to UWI. Available at: http://www.uwi.edu/about.asp

[8] Faculty of Engineering (2019). Undergraduate Regulations and Syllabuses 2019/2020. Available at: https://sta.uwi.edu/resources/documents/facultybooklets/EngUndergrad.pdf

[9] Engineering Council (ECUT), 2005 (reprinted), UK Standard for Professional Engineering Competence: Chartered Engineer and Incorporated Engineer Standard.

[10] P. Whitley. 1999. Quality Assurance and Quality Audit at the University of the West Indies: Procedures and Practice, Office of the Board for Undergraduate Studies, The University of the West Indies, Mona, Kingston, Jamaica.

[11] Caribbean Accreditation Council for Engineering and Technology. 2009. Available at: https://www.slideserve.com/axl/caribbean-accreditation-council-for-engineering-and-technology 